\title{
Organo-modified layered double hydroxide-catalyzed Fenton-like ultra-weak chemiluminescence for specific sensing of vitamin $B_{12}$ in egg yolks
}

\author{
Lijuan Zhang ${ }^{\mathrm{a}}$, Wanqi Rong ${ }^{\mathrm{a}}$, Chao $\mathrm{Lu}^{\mathrm{a}, *}$, Lixia Zhao ${ }^{\mathrm{b}}$ \\ a State Key Laboratory of Chemical Resource Engineering, Beijing University of Chemical Technology, Beijing 100029, China \\ b State Key Laboratory of Environmental Chemistry and Ecotoxicology, Research Center for Eco-Environmental Sciences, Chinese Academy of Sciences, Beijing \\ 100085, China
}

\section{A R T I C L E I N F O}

\section{Article history:}

Received 26 February 2014

Received in revised form

16 May 2014

Accepted 20 May 2014

Available online 28 May 2014

Keywords:

Organo-modified layered double hydroxides

Fenton-like reaction

Chemiluminescence

Vitamin $\mathrm{B}_{12}$

\begin{abstract}
A B S T R A C T
In general, the chemiluminescence $(\mathrm{CL})$ sensing of vitamin $\mathrm{B}_{12}$ is achieved by determining $\mathrm{Co}(\mathrm{II})$ liberated from acidified vitamin $B_{12}$ by a luminol system. However, the luminol system for sensing vitamin $\mathrm{B}_{12}$ has poor selectivity due to serious interference from other metal ions. In this study, as a novel $\mathrm{CL}$ amplifier of the $\mathrm{Co}(\mathrm{II})+\mathrm{H}_{2} \mathrm{O}_{2}+\mathrm{OH}^{-}$ultra-weak $\mathrm{CL}$ reaction (Fenton-like system), dodecylbenzene sulfonate (DBS)-layered double hydroxides (LDHs) have been applied to the specific determination of vitamin $\mathrm{B}_{12}$ by liberating $\mathrm{Co}(\mathrm{II})$. The $\mathrm{CL}$ intensity increased with increasing the concentration of vitamin $B_{12}$ in a wide range from $1.0 \mathrm{ng} \mathrm{mL}^{-1}$ to $5 \mu \mathrm{g} \mathrm{mL}^{-1}$ with a detection limit of $0.57 \mathrm{ng} \mathrm{mL}^{-1}(\mathrm{~S}$ ) $N=3$ ). The proposed method has been successfully applied to determine vitamin $\mathrm{B}_{12}$ in egg yolk with simple procedures, shorter time and higher selectivity. Recoveries from spiked real samples were 96$103 \%$. The results of the proposed method for sensing vitamin $B_{12}$ in real samples were agreed with those obtained by the standard inductively coupled plasma mass spectrometry (ICP-MS) method. To the best of our knowledge, this is the first report on the CL sensing of vitamin $B_{12}$ with high selectivity in the absence of luminol.
\end{abstract}

(c) 2014 Elsevier B.V. All rights reserved.

\section{Introduction}

Vitamin $B_{12}$ is an essential nutrient linked to human growth and cell development [1]. The daily requirement of vitamin $B_{12}$ is relatively low in comparison to other vitamins, and thus exposure to excessive amounts of vitamin $\mathrm{B}_{12}$ can induce asthma and folic acid deficiency [2]. On the other hand, its deficiency is associated with a variety of disorders and human diseases, such as weakness, fatigue, renal dysfunction, diabetes, pernicious anemia and nerve degeneration [3]. It is well known that vitamin $B_{12}$ must be obtained through diet because it cannot be synthesized in the human body [4]. Acting as a nutrient-dense food, eggs contain a substantial amount of various essential vitamins, and thus they are considered as an important source of vitamin $B_{12}$, in which vitamin $B_{12}$ is mainly found in egg yolks [5]. As a result, the accurate measurement of vitamin $B_{12}$ in egg yolks is desirable for research purposes and routine clinical use.

The classical analytical techniques for quantifying vitamin $\mathrm{B}_{12}$ currently include microbiological [6], spectrophotometric [7],

\footnotetext{
* Corresponding author. Tel.: +8610 64411957.

E-mail address: luchao@mail.buct.edu.cn (C. Lu).
}

fluorescent [8], inductively coupled plasma mass spectrometry (ICP-MS) [9], and electrochemical methods [10]. Nowadays, a chemiluminescence $(\mathrm{CL})$ technique for the determination of vitamin $B_{12}$ is becoming a promising technique with reliability, fast response, cheap instrument, simple operation and high sensitivity [11-15]. Generally, the quantification of vitamin $B_{12}$ could be achieved by determining $\mathrm{Co}(\mathrm{II})$ liberated from acidified vitamin $\mathrm{B}_{12}$ using the luminol $\mathrm{CL}$ system. However, these $\mathrm{CL}$ methods suffered from the low selectivity due to serious interference from other metal ions. Therefore, it is highly desired to employ the other CL systems in the absence of luminol for improving the CL selectivity towards vitamin $\mathrm{B}_{12}$. To the best of our knowledge, the specific and precise CL measurements of vitamin $B_{12}$ are not available except for the luminol system at present. As a result, it is still an active field as well as a great challenge to attain this goal.

Layered double hydroxides (LDHs) are an important class of host-guest layered nanomaterials consisting of positively charged metal hydroxide sheets with charge-balancing intercalated anions and water molecules [16,17]. LDHs exhibit a well-defined layered structure with relatively large surface area, high porosity, high layer charge density and interlayer anion mobility [18]. Therefore, LDHs have been extensively employed as catalysts, ion exchangers, and adsorbents [19-22]. Recently, we have found that the galleries 


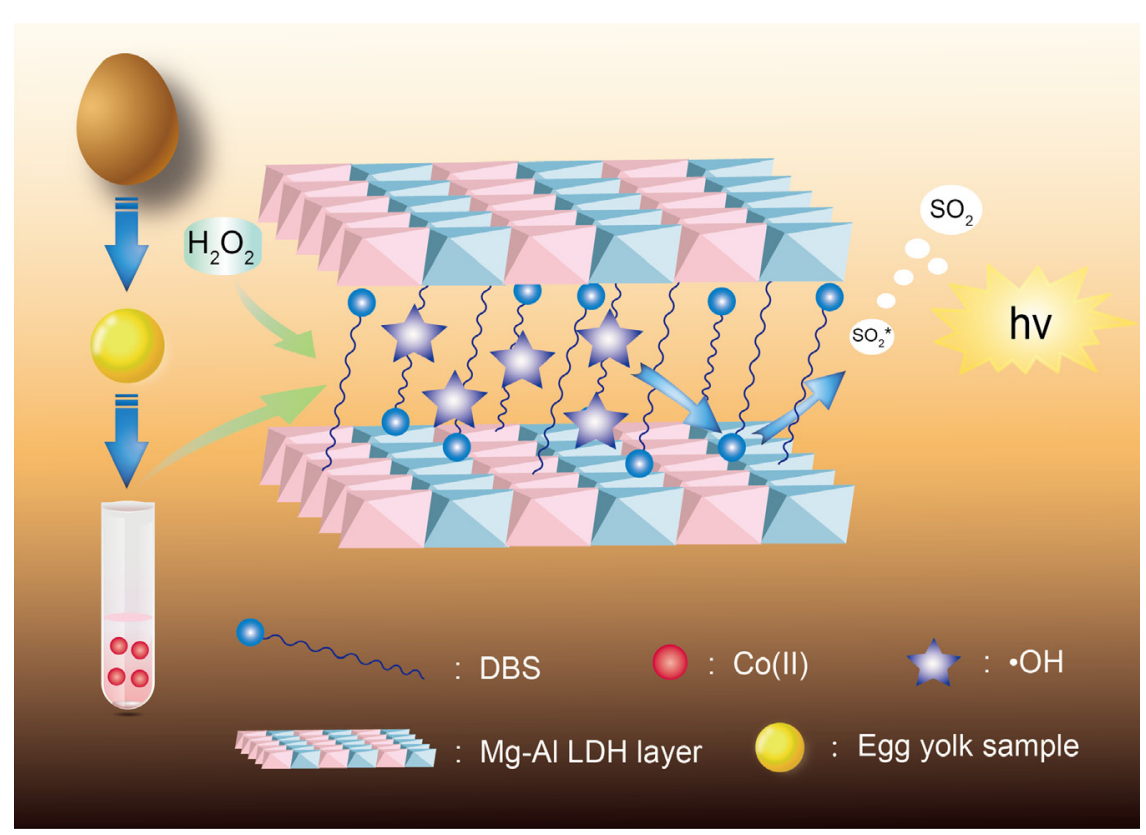

Fig. 1. Possible mechanism for the DBS-LDH- $\mathrm{Co}(\mathrm{II})+\mathrm{H}_{2} \mathrm{O}_{2}+\mathrm{OH}^{-}$system.

of the LDH could lead to the concentration of the CL reactants/ intermediates on the surface or in the interlayer of the LDHs, facilitating the occurrence of the CL reactions [23,24]. It has been reported that the $\mathrm{LDHs}$ can enhance the $\mathrm{CL}$ signals of some ultraweak CL systems, such as the $\mathrm{IO}_{4}^{-}-\mathrm{H}_{2} \mathrm{O}_{2}$ system, and peroxynitrous acid system [25-27]. Subsequently, the LDH-amplified ultra-weak CL emissions were successfully used for a wide variety of analytes in environmental and food samples [28-30].

Recently, we reported that organo-modified LDHs (i.e., dodecylbenzene sulfonate DBS-modified LDHs) could significantly enhance an ultra-weak $\mathrm{CL}$ from Fenton-like reaction $(\mathrm{Co}(\mathrm{II})+$ $\mathrm{H}_{2} \mathrm{O}_{2}+\mathrm{OH}^{-}$) [31]. The DBS-modified LDH-induced CL enhancement of Fenton-like reaction was ascribed to the hydrophobic microenvironment of the intercalated DBS in LDHs, facilitating the formation of reaction intermediates. In this study, we tried to detect $\mathrm{Co}$ (II) liberated from acidified vitamin $\mathrm{B}_{12}$ using the DBS-modified LDH-catalyzed Fenton-like CL system (Fig. 1). It was found that the $\mathrm{CL}$ intensity was proportional to the log concentration of vitamin $B_{12}$ in the range from $1.0 \mathrm{ng} \mathrm{mL}^{-1}$ to $5 \mu \mathrm{g} \mathrm{mL}^{-1}$, and the limit of detection $(S / N=3)$ was found to be as low as $0.57 \mathrm{ng} \mathrm{mL} \mathrm{m}^{-1}$. Therefore, a rapid, selective, sensitive and simple $\mathrm{CL}$ method to assay vitamin $B_{12}$ was successfully developed. Validation of the proposed method was checked by determining vitamin $\mathrm{B}_{12}$ in egg yolks. To the best of our knowledge, here is the first example for CL sensing of vitamin $B_{12}$ with high selectivity in the absence of luminol.

\section{Experimental}

\subsection{Reagents}

Analytical grade chemicals including $\mathrm{NaOH}, \mathrm{Mg}\left(\mathrm{NO}_{3}\right)_{2} \cdot 6 \mathrm{H}_{2} \mathrm{O}$, $\mathrm{Al}\left(\mathrm{NO}_{3}\right)_{3} \cdot 9 \mathrm{H}_{2} \mathrm{O}, \mathrm{HCl}, \mathrm{HNO}_{3}, \mathrm{H}_{2} \mathrm{O}_{2}, \mathrm{FeSO}_{4} \cdot 7 \mathrm{H}_{2} \mathrm{O}, \mathrm{FeCl}_{3}, \mathrm{CuCl}_{2} \cdot 2 \mathrm{H}_{2} \mathrm{O}$, $\mathrm{MnSO}_{4} \cdot \mathrm{H}_{2} \mathrm{O}, \mathrm{Ni}\left(\mathrm{NO}_{3}\right)_{2} \cdot 6 \mathrm{H}_{2} \mathrm{O}, \mathrm{Pb}\left(\mathrm{NO}_{3}\right)_{2}, \mathrm{CrCl}_{3} \cdot 6 \mathrm{H}_{2} \mathrm{O}$, and $\mathrm{ZnCl}_{2}$ were purchased from Beijing Chemical Reagent Company (Beijing, China). Uranine was purchased from Acros. Sodium dodecyl benzene sulfonate (SDBS) was purchased from Tokyo Chemical Industry Co. Ltd. Pure crystalline vitamin $\mathrm{B}_{12}$ was purchased from Beijing HWRK Chem Co. Ltd. Working solutions of $\mathrm{H}_{2} \mathrm{O}_{2}$ were prepared daily from $30 \%(v / v) \mathrm{H}_{2} \mathrm{O}_{2}$. A stock solution of vitamin $\mathrm{B}_{12}$
(1.0 $\mathrm{mg} \mathrm{mL}^{-1}$ ) was prepared by dissolving $0.100 \mathrm{~g}$ of crystalline vitamin $B_{12}$ in $100 \mathrm{~mL}$ deionized water. All reagents were of analytical grade and used without further purification. All solutions were prepared with deionized water (Milli Q Millipore, Barnstead, CA, USA).

\subsection{Apparatus}

The powder X-ray diffraction (XRD) measurement was performed on a Bruker (Germany) D8 ADVANCE X-ray diffractometer equipped with graphite-monochromatized $\mathrm{Cu} / \mathrm{K} \alpha$ radiation $(\lambda=$ $1.5406 \AA$ ). The $2 \theta$ angle of the diffractometer was stepped from $2^{\circ}$ to $70^{\circ}$ at a scan rate of $0.02^{\circ} \mathrm{s}$. The particle sizes and external morphology of the samples were observed on a transmission electron microscope (TEM, Tecnai G220, FEI Company). Scanning electron microscopy (SEM) was measured on a Hitachi (Japan) S-4700 field-emission scanning electron microscope. The fluorescence spectra were obtained using a F-7000 fluorescence spectrophotometer (Hitachi, Tokyo, Japan) at a scanning rate of $1500 \mathrm{~nm} /$ min. The excitation slit and the emission slit were maintained at $5.0 \mathrm{~nm}$ and $2.5 \mathrm{~nm}$, respectively. The $\mathrm{CL}$ detection was conducted on an Ultra-Weak Luminescence Analyzer, which was purchased from institute of Biophysics, Chinese Academy of Science, Beijing, China (Biophysics Chemiluminescence, BPCL). An Agilent 7700 ICP-MS system (Agilent Technologies, Santa Clara, CA) was used to detect the $\mathrm{Co}(\mathrm{II})$ in egg yolks.

\subsection{Synthesis of $\mathrm{Mg}-\mathrm{Al}-\mathrm{-NO} \mathrm{O}_{3} \mathrm{LDHs}$}

The $\mathrm{Mg}-\mathrm{Al}-\mathrm{NO}_{3} \mathrm{LDHs}$ with different $\mathrm{Mg} / \mathrm{Al}$ molar ratios were obtained by a co-precipitation method. The precipitation process was taken under low supersaturation conditions at constant $\mathrm{pH}$. For $\mathrm{Mg} / \mathrm{Al}$ molar ratio of 3, the salt solution $(80 \mathrm{~mL})$ containing $\mathrm{Mg}$ $\left(\mathrm{NO}_{3}\right)_{2} \cdot 6 \mathrm{H}_{2} \mathrm{O}(0.06 \mathrm{~mol})$ and $\mathrm{Al}\left(\mathrm{NO}_{3}\right)_{3} \cdot 9 \mathrm{H}_{2} \mathrm{O}(0.02 \mathrm{~mol})$ was added dropwise to a $250 \mathrm{~mL}$ four-necked flask under vigorous stirring at room temperature, the $\mathrm{pH}$ value was adjusted to 10 with $2.0 \mathrm{M}$ $\mathrm{NaOH}$. The resulting white precipitate was continually stirred for $24 \mathrm{~h}$ at $65{ }^{\circ} \mathrm{C}$. The whole reaction process was purged with $\mathrm{N}_{2}$ throughout the experiment to avoid carbon dioxide uptake. The products were centrifugated, washed with degassed and deionized 
water for three times, dried in vacuo at $65^{\circ} \mathrm{C}$ for $24 \mathrm{~h}$ and ground to a fine powder.

\subsection{Synthesis of $M g-A l-D B S L D H s$}

The typical anion exchange procedure was used to prepared Mg-Al-DBS LDHs. A $0.2 \mathrm{M}$ SDBS aqueous solution $(25 \mathrm{~mL})$ was prepared by degassed and deionized water. A suspension of $1.0 \mathrm{~g}$ $\mathrm{Mg}-\mathrm{Al}-\mathrm{NO}_{3} \mathrm{LDHs}$ in the prepared SDBS solution was vigorously stirred at $80{ }^{\circ} \mathrm{C}$ for $24 \mathrm{~h}$ under nitrogen atmosphere. The as-prepared $\mathrm{Mg}-\mathrm{Al}-\mathrm{DBS} \mathrm{LDH}$ suspension was stored at $4{ }^{\circ} \mathrm{C}$ for further use.

\subsection{Acidification of standard vitamin $B_{12}$}

It is important to acidify vitamin $\mathrm{B}_{12}$ for the liberation of $\mathrm{Co}(\mathrm{II})$ using $\mathrm{HNO}_{3}$ and $\mathrm{HCl}$ in order to further $\mathrm{CL}$ assay. Herein, vitamin $\mathrm{B}_{12}$ was acidified according to the literature [14]. Briefly, $1.0 \mathrm{mg} \mathrm{mL}^{-1}$ vitamin $\mathrm{B}_{12}$ was acidified with $5.0 \mathrm{~mL}$ of $5.0 \mathrm{M} \mathrm{HNO}_{3}$ by heating until the solution was evaporated completely, followed by adding $5.0 \mathrm{~mL}$ of $3.0 \mathrm{M} \mathrm{HCl}$ to remove the redundant $\mathrm{HNO}_{3}$. The reaction mixture was further heated at $95{ }^{\circ} \mathrm{C}$ for $4 \mathrm{~min}$ and cooled at room temperature; the $\mathrm{pH}$ value of the obtained residue was adjusted to $\mathrm{pH} 7.0$ with $5.0 \mathrm{M} \mathrm{NaOH}$. The as-prepared solution was diluted with deionized water when required before the $\mathrm{CL}$ analysis.

\subsection{Procedure for $C L$ detection}

The schematic diagram of the CL system was shown in Fig. S1. $200 \mu \mathrm{L} 10 \mu \mathrm{g} \mathrm{mL}^{-1}$ acidified vitamin $\mathrm{B}_{12}$ solution was injected into the mixed solution containing $200 \mu \mathrm{L} 100 \mathrm{mM} \mathrm{Mg-Al-DBS} \mathrm{LDH}$ suspension and $100 \mu \mathrm{L} 1.0 \mathrm{mM} \mathrm{H} \mathrm{H}_{2} \mathrm{O}_{2}$. The CL signals were monitored by a photomultiplier tube (PMT) adjacent to the CL quartz cell. The data integration time of the BPCL analyzer was set at $0.1 \mathrm{~s}$ per spectrum, and a work voltage of $-1000 \mathrm{~V}$ was used for the $\mathrm{CL}$ detection. The CL signals were imported to the computer for data acquisition.

\subsection{Sample pretreatment}

Eggs from the supermarket in Beijing were pretreated according to the literature [13]. $5.0 \mathrm{~g}$ of boiled egg yolk was accurately weighed, and then it was ground and acidified ultrasonically with $50 \mathrm{~mL}$ of $0.5 \mathrm{M} \mathrm{HCl}$ until a homogeneous mixture was obtained. The obtained mixture was then centrifuged at $10,000 \mathrm{rpm}$ for $10 \mathrm{~min}$. The clear supernatant was filtered through a $0.45 \mu \mathrm{m}$ filter and diluted as required prior to analysis. The as-prepared products were analyzed immediately by the proposed CL method and a standard ICP-MS method.

\section{Results and discussion}

\subsection{Selective sensing towards $C o(I I)$ in Fenton-like-DBS-LDH CL system}

The CL assays of $\mathrm{Co}(\mathrm{II})$ using luminol reaction system generally exhibit high sensitivity, but the detection selectivity towards $\mathrm{Co}(\mathrm{II})$ is relatively low [32,33]. Therefore, it is highly required to use sample pretreatments or separation techniques to improve the $\mathrm{CL}$ selectivity towards $\mathrm{Co}(\mathrm{II})$. In this study, the $\mathrm{CL}$ intensity of the DBS-LDH-amplified Fenton-like system of a series of metal ions was investigated in a static CL system established in Fig. S1. As shown in Fig. 2, an obvious increase in the CL intensity was observed upon the addition of $1.0 \mu \mathrm{M} \mathrm{Co}(\mathrm{II})$. However, little CL change occurred in the presence of common metal ions including $\mathrm{Fe}(\mathrm{III}), \mathrm{Fe}(\mathrm{II}), \mathrm{Pb}(\mathrm{II}), \mathrm{Cu}(\mathrm{II}), \mathrm{Mn}(\mathrm{II}), \mathrm{Zn}(\mathrm{II}), \mathrm{Ni}(\mathrm{II}), \mathrm{Cr}(\mathrm{III})$, and $\mathrm{Al}(\mathrm{III})$. Therefore, it is concluded that the present CL system is highly selective towards $\mathrm{Co}(\mathrm{II})$

It has been reported that $\mathrm{Cu}(\mathrm{II})$ can also catalyze the decomposition of $\mathrm{H}_{2} \mathrm{O}_{2}$ in basic solutions to produce a weak $\mathrm{CL}$ emission (i.e., $\mathrm{Cu}(\mathrm{II})+\mathrm{H}_{2} \mathrm{O}_{2}+\mathrm{OH}^{-}$system) [34,35]. Accordingly, in order to clarify the mechanism of the striking CL selectivity towards $\mathrm{Co}(\mathrm{II})$, the kinetic CL intensity-time profiles for DBS-LDH-Co(II)+ $\mathrm{H}_{2} \mathrm{O}_{2}+\mathrm{OH}^{-}$system and DBS--LDH-Cu(II) $+\mathrm{H}_{2} \mathrm{O}_{2}+\mathrm{OH}^{-}$system were almost the same (maximum at $0.3 \mathrm{~s}$ ) except for the

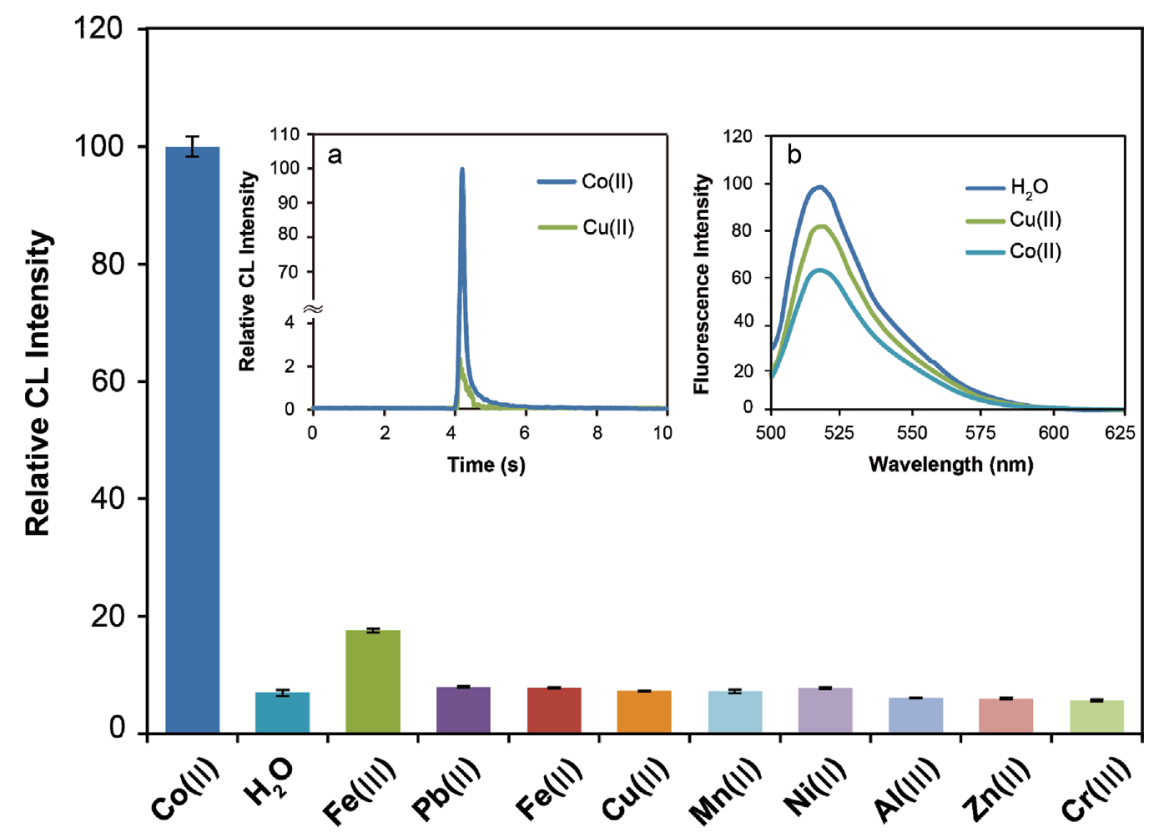

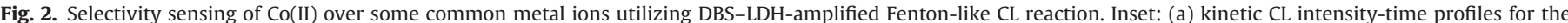

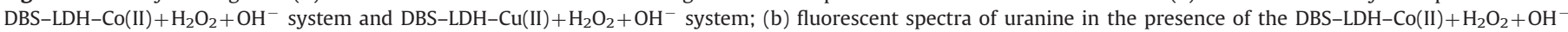

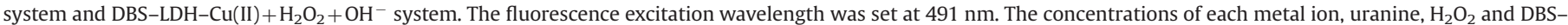
LDH colloidal solution were $1.0 \mu \mathrm{M}, 1.0 \mathrm{mM}, 1.0 \mathrm{mM}$ and $20 \mathrm{mg} \mathrm{mL}^{-1}$, respectively. 
differences of the CL intensities (see inset a of Fig. 2). These results indicated that the $\mathrm{CL}$ reaction rate of the DBS-LDH-Co(II)+ $\mathrm{H}_{2} \mathrm{O}_{2}+\mathrm{OH}^{-}$system was the same as that of the DBS-LDH-Cu (II) $+\mathrm{H}_{2} \mathrm{O}_{2}+\mathrm{OH}^{-}$system; however, the amount of the intermediates generated during the $\mathrm{CL}$ reactions from the DBS- $\mathrm{LDH}-\mathrm{Co}(\mathrm{II})+$ $\mathrm{H}_{2} \mathrm{O}_{2}+\mathrm{OH}^{-}$system was much more than that from the DBS-LDH$\mathrm{Cu}(\mathrm{II})+\mathrm{H}_{2} \mathrm{O}_{2}+\mathrm{OH}^{-}$system. On the other hand, the DBS-LDH-Co (II) $+\mathrm{H}_{2} \mathrm{O}_{2}+\mathrm{OH}^{-}$system could lead to a greater decrease in the fluorescence intensity of uranine in comparison to the DBS-LDH$\mathrm{Cu}(\mathrm{II})+\mathrm{H}_{2} \mathrm{O}_{2}+\mathrm{OH}^{-}$system (see inset b of Fig. 2), indicating the formation of the larger amount of hydroxyl radicals $(\bullet \mathrm{OH})$ in the presence of the DBS-LDH-Co(II) $+\mathrm{H}_{2} \mathrm{O}_{2}+\mathrm{OH}^{-}$system [36].

\section{2. $\mathrm{Mg}$ to Al molar ratios}

In this study, the effect of $\mathrm{Mg} / \mathrm{Al}$ molar ratios of $\mathrm{Mg}-\mathrm{Al} \mathrm{DBS}-$ LDHs between 2 and 4 on the CL intensity was investigated. The results showed that the CL intensity of the proposed system with $\mathrm{Mg} / \mathrm{Al}$ molar ratio 3 was the strongest, and the higher and lower $\mathrm{Mg} / \mathrm{Al}$ ratios resulted in a decrease of the CL intensity. The SEM image, TEM image and the representative XRD pattern of DBSLDHs with a $\mathrm{Mg} / \mathrm{Al}$ ratio of 3 indicated that the well-order layered structures with a high degree of crystallinity were formed (Fig. S2), facilitating the proceeding of the $\mathrm{CL}$ reaction. These results were almost in conformity with the literature [23].

\subsection{Concentrations of $\mathrm{H}_{2} \mathrm{O}_{2}$ and DBS-LDH colloidal solution}

The concentration of $\mathrm{H}_{2} \mathrm{O}_{2}$ was a key parameter for the DBS$\mathrm{LDH}-\mathrm{Co}(\mathrm{II})+\mathrm{H}_{2} \mathrm{O}_{2}+\mathrm{OH}^{-} \mathrm{CL}$ reaction. In this study, the effect of the concentration of $\mathrm{H}_{2} \mathrm{O}_{2}$ on the $\mathrm{CL}$ intensity was examined in the range of $0.5-10 \mathrm{mM}$ (Fig. 3a). The results showed that the strongest CL intensity was observed at $1.0 \mathrm{mM} \mathrm{H}_{2} \mathrm{O}_{2}$, accompanying with the production of a small number of gaseous bubbles. The concentrations of $\mathrm{H}_{2} \mathrm{O}_{2}$ higher than $1.0 \mathrm{mM}$ could induce a decrease in the $\mathrm{CL}$ intensity. Therefore, this system was operated at $1.0 \mathrm{mM} \mathrm{H}_{2} \mathrm{O}_{2}$ throughout this study.

On the other hand, the DBS-LDH colloidal solution can act as an efficient amplifier of the $\mathrm{Co}(\mathrm{II})+\mathrm{H}_{2} \mathrm{O}_{2}+\mathrm{OH}^{-} \mathrm{CL}$ reaction. Therefore, the concentration of DBS-LDHs played an important role in CL intensity. Note that the concentration of the as-prepared DBSLDHs was calculated to be $56 \mathrm{mg} \mathrm{mL}^{-1}$ by measuring the obtained solid content. As shown in Fig. 3b, the effect of the concentration of DBS-LDHs on the CL in the range of $5.0-56 \mathrm{mg} \mathrm{mL}^{-1}$ was investigated. It was shown that the maximum intensity was obtained at a DBS-LDHs concentration of $20 \mathrm{mg} \mathrm{mL}^{-1}$. When the concentrations of DBS-LDHs were higher than $20 \mathrm{mg} \mathrm{mL}^{-1}$, the CL intensity increased slowly. In view of the consumption of the reagents, $20 \mathrm{mg} \mathrm{mL}^{-1}$ was used as the optimal concentration of DBS-LDH colloidal solution.

\subsection{Analytical performances}

Under the optimum experimental conditions employed in this study, the CL intensity was proportional to the log concentration of vitamin $B_{12}$ in the range from $1.0 \mathrm{ng} \mathrm{mL}^{-1}$ to $5 \mu \mathrm{g} \mathrm{mL}^{-1}$ (Fig. 4). The regression equation was $\Delta I=25.02 \log C+4.2288\left(R^{2}=0.997\right)$, where $\Delta I$ was the relative $C L$ intensity and $C$ was the concentration of vitamin $B_{12}$, respectively. The detection limit for vitamin $B_{12}$ $(S / N=3)$ was calculated to be $0.57 \mathrm{ng} \mathrm{mL}^{-1}$ [13]. The relative standard deviation (RSD) for nine repeated measurements of $10 \mathrm{ng} \mathrm{mL}{ }^{-1}$ vitamin $\mathrm{B}_{12}$ was $2.8 \%$. Furthermore, the interference effects of various coexistent substances presented in egg yolk samples on the determination of vitamin $B_{12}$ were examined. A sample solution containing a fixed amount of vitamin $B_{12}$ (10 ng mL ${ }^{-1}$ ) and different concentrations of each coexistent substance was analyzed by the proposed method. A coexistent substance was considered as non-interfering if the analytical CL signal variation was $\pm 5 \%$ in comparison to the CL signal obtained in the absence of the coexistent substance. The results revealed that the proposed method showed very high selectivity towards vitamin $\mathrm{B}_{12}$ (Table 1 ).

\subsection{Real samples}

In order to evaluate the applicability and reliability of the proposed methodology, it was applied for the determination of vitamin $B_{12}$ in egg yolk samples. The pretreated samples were diluted to an appropriate concentration with deionized water before analysis. To check the accuracy of the $\mathrm{CL}$ analysis, a standard ICP-MS method was used to measure the content of Co (II) liberated from acidified vitamin $\mathrm{B}_{12}$ in egg yolk samples. The results in Table 2 indicate that vitamin $B_{12}$ can be detected in real sample and no obvious difference was observed between the proposed method and the standard ICP-MS method. These differences were statistically insignificant $(P>0.05)$ when the sample groups were used to undergo two-tailed unpaired $T$-tests [13]. The recoveries of vitamin $B_{12}$ obtained by the proposed method ranged from $96 \%$ to $103 \%$. These results demonstrated that the present method could be efficiently used to determine vitamin $B_{12}$ in egg yolk samples.

\section{Conclusions}

In summary, the organo-modified LDHs were found to have a remarkable amplification of Fenton-like reaction of $\mathrm{Co}(\mathrm{II}) \mathrm{CL}$ reaction in basic solutions. The differences of the $\mathrm{CL}$ reaction kinetics and fluorescence intensity variation of uranine resulted from the DBS-LDH-Co(II) $+\mathrm{H}_{2} \mathrm{O}_{2}+\mathrm{OH}^{-}$system and the DBS-LDH$\mathrm{Cu}(\mathrm{II})+\mathrm{H}_{2} \mathrm{O}_{2}+\mathrm{OH}^{-}$system demonstrated that the larger amount

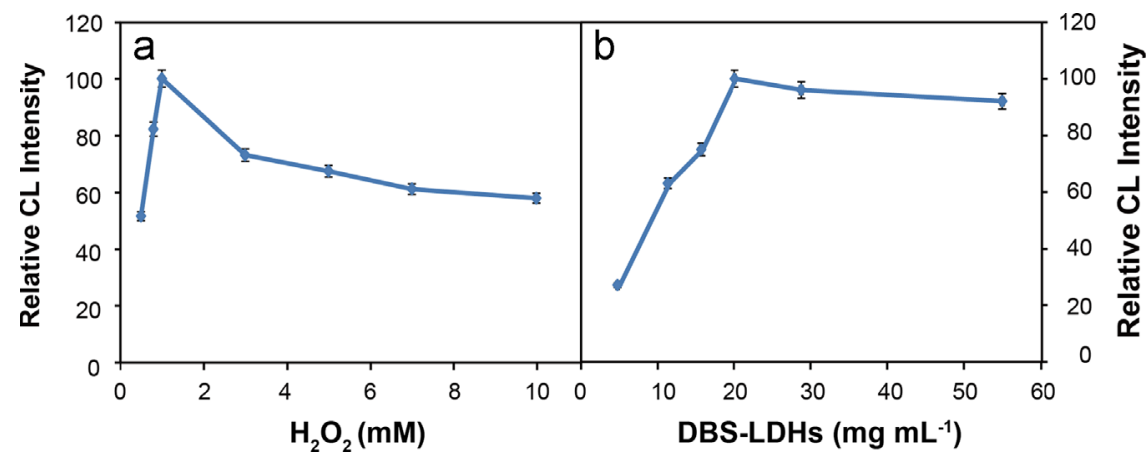

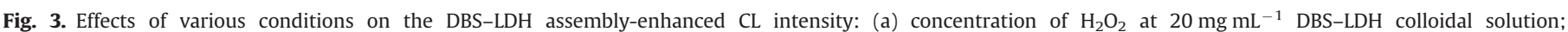
(b) concentration of DBS-LDH colloidal solution at $1.0 \mathrm{mM} \mathrm{H}_{2} \mathrm{O}_{2}$. 


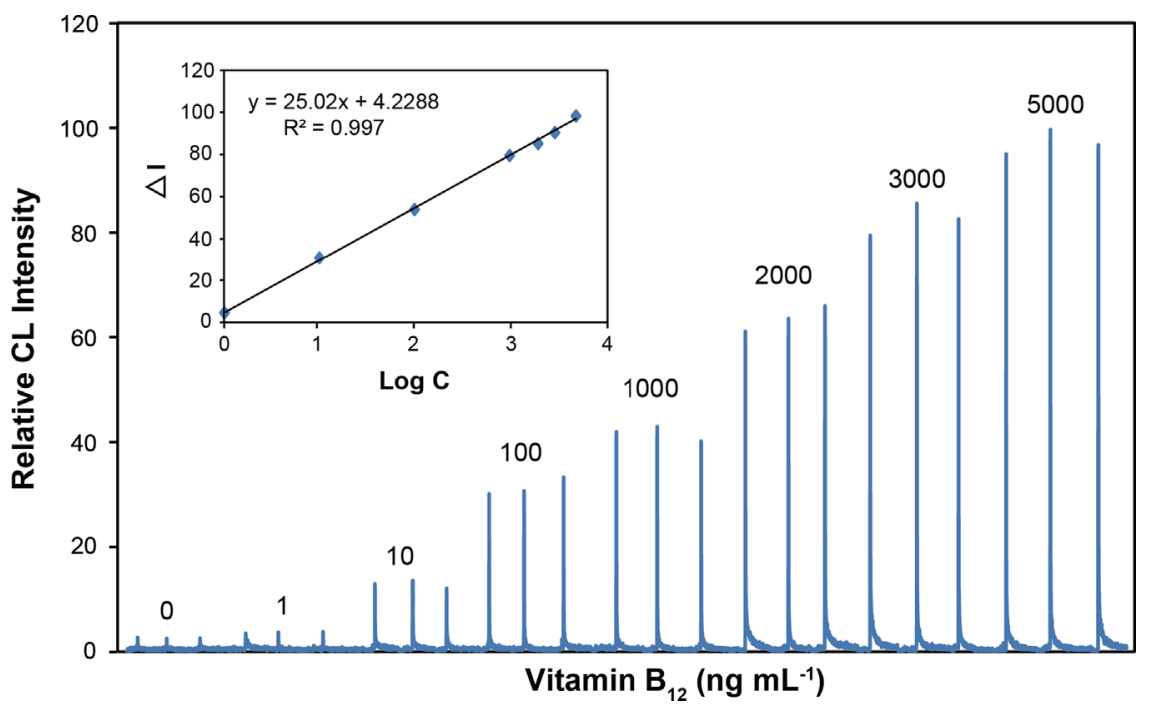

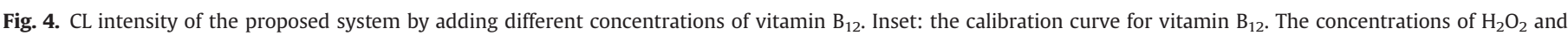
DBS-LDH colloidal solution were $1.0 \mathrm{mM}$ and $20 \mathrm{mg} \mathrm{mL}^{-1}$, respectively.

Table 1

Tolerance limit of various coexistent substances on the determination of $10.0 \mathrm{ng} \mathrm{mL}^{-1}$ vitamin $\mathrm{B}_{12}$.

\begin{tabular}{ll}
\hline $\begin{array}{l}\text { Tolerance } \\
\left(\mathrm{ng} \mathrm{mL} \mathrm{mL}^{-1}\right)\end{array}$ & Coexistent substances \\
\hline $1.0 \times 10^{5}$ & $\begin{array}{l}\mathrm{Na}^{+}, \mathrm{Mg}^{2+}, \mathrm{Al}^{3+}, \mathrm{NO}_{3}^{-}, \mathrm{F}^{-}, \mathrm{Cl}^{-}, \mathrm{Br}^{-}, \mathrm{SO}_{4}^{2-}, \mathrm{SO}_{3}^{2-}, \mathrm{CO}_{3}^{2-}, \mathrm{HCO}_{3}^{-}, \text {glucose, } \\
\text { sucrose } \\
\mathrm{Ca}^{2+}, \mathrm{Ag}^{+}, \mathrm{Fe}^{2+}, \mathrm{Sn}^{2+}, \mathrm{Sr}^{2+}, \mathrm{Zn}^{2+}, \mathrm{Ba}^{2+}, \mathrm{K}^{+}, \mathrm{Ac}^{-}, \mathrm{H}_{2} \mathrm{PO}_{4}^{-}, \mathrm{HPO}_{4}^{2-}, \mathrm{C}_{2} \mathrm{O}_{4}^{2-} \\
\mathrm{Cu}^{2+}, \mathrm{Cr}^{3+}, \mathrm{Cd}^{2+}, \mathrm{Fe}^{3+}, \mathrm{Ni}^{2+}, \mathrm{Pb}^{2+}, \mathrm{Mn}^{2+}\end{array}$ \\
\hline
\end{tabular}

Table 2

Determination of vitamin $B_{12}$ in egg yolk samples.

\begin{tabular}{|c|c|c|c|c|c|}
\hline Samples & CL method ${ }^{\mathrm{a}}\left(\mathrm{ng} \mathrm{g}^{-1}\right)$ & ICP-MS method $^{\mathrm{a}}\left(\mathrm{ng} \mathrm{g}^{-1}\right)$ & Added $\left(\mathrm{ng} \mathrm{g}^{-1}\right)$ & Found $^{\mathrm{a}}\left(\mathrm{ng} \mathrm{g}^{-1}\right)$ & Recovery (\%) \\
\hline Egg yolk 1 & $75.7 \pm 0.1$ & $72.3 \pm 1.6$ & 80.0 & $79.4 \pm 1.1$ & $99 \pm 1.3$ \\
\hline Egg yolk 2 & $80.6 \pm 0.2$ & $78.9 \pm 2.1$ & 80.0 & $82.6 \pm 0.5$ & $103 \pm 0.6$ \\
\hline Egg yolk 3 & $78.1 \pm 1.1$ & $75.2 \pm 0.7$ & 80.0 & $77.1 \pm 0.2$ & $96 \pm 0.2$ \\
\hline Egg yolk 4 & $67.5 \pm 0.3$ & $69.4 \pm 1.3$ & 60.0 & $59.1 \pm 0.6$ & $98 \pm 1.0$ \\
\hline Egg yolk 5 & $60.2 \pm 0.7$ & $57.9 \pm 3.1$ & 60.0 & $61.4 \pm 0.9$ & $102 \pm 1.5$ \\
\hline
\end{tabular}

a Mean \pm SD of three measurements.

of $\bullet \mathrm{OH}$ radicals in the presence of the DBS-LDH-Co(II)+ $\mathrm{H}_{2} \mathrm{O}_{2}+\mathrm{OH}^{-}$system may be responsible for the highly selective response of the present $\mathrm{CL}$ system towards $\mathrm{Co}(\mathrm{II})$. More interestingly, the developed CL sensitizer in this work can avoid serious interference from other metal ions generally encountered in the previous $\mathrm{CL}$ sensors for vitamin $\mathrm{B}_{12}$ with the most common luminol reagent. Therefore, the DBS-LDH-Co(II) $+\mathrm{H}_{2} \mathrm{O}_{2}+\mathrm{OH}^{-} \mathrm{CL}$ system can be applied to the specific determination of vitamin $\mathrm{B}_{12}$ in egg yolk samples by liberating $\mathrm{Co}(\mathrm{II})$ with high sensitivity and selectivity. The obtained results of the proposed method were in good agreement with ones obtained by a standard ICP-MS method.

\section{Acknowledgments}

This work was supported by the National Natural Science Foundation of China (21375006 and 21177138), the 973 Program (2011CBA00503), and the Fundamental Research Funds for the Central Universities (JD1311). We also thank Prof. Xue Duan,
Beijing University of Chemical Technology for his valuable discussions.

\section{Appendix A. Supporting information}

Supplementary data associated with this article can be found in the online version at http://dx.doi.org/10.1016/j.talanta.2014.05. 041.

\section{References}

[1] L.R. Solomon, Blood Rev. 21 (2007) 113-130.

[2] A.A. Yates, S.A. Schlicker, C.W. Suitor, J. Am. Diet. Assoc. 98 (1998) 699-706.

[3] R. Obeid, B. Shannan, W. Herrmann, Med. Hypotheses 77 (2011) 884-888.

[4] T. Kwok, G. Cheng, J. Woo, W.K. Lai, C.P. Pang, J. Anal. Toxicol. 70 (2002) $186-190$.

[5] E.C. Naber, J. Appl. Poult. Res. 2 (1993) 385-393.

[6] E. Miyamoto, Y. Tanioka, T. Nakao, F. Barla, H. Inui, T. Fujita, F. Watanabe Y. Nakano, J. Agric. Food Chem. 54 (2006) 9604-9607.

[7] P. Chen, W.R. Wolf, I. Castanheira, A. Sanches-Silva, Anal. Methods 2 (2010) $1171-1175$. 
[8] F. Samari, B. Hemmateenejad, Z. Rezaei, M. Shamsipur, Anal. Methods 4 (2012) 4155-4160.

[9] C.S.K. Raju, L.Y. Lee, J.E. Schiel, S.E. Long, J. Anal. At. Spectrom. 28 (2013) 901-907.

[10] P. Tomčik, C.E. Banks, T.J. Davies, Anal. Chem. 76 (2004) 161-165.

[11] M. Kamruzzaman, A.-M. Alam, K.M. Kim, S.H. Lee, Y.H. Kim, A.N.M.H. Kabir, G.M. Kim, T.D. Dang, Biomed. Microdevices 15 (2013) 195-202.

[12] J.A. Murillo Pulgarín, L.F. García Bermejo, M. Nieves Sánchez García, Luminescence 26 (2011) 536-542.

[13] K.S. Lok, S.Z.b.A. Muttalib, P.P.F. Lee, Y.C. Kwok, N.-T. Nguyen, Lab Chip 12 (2012) 2353-2361.

[14] S.S. Kumar, R.S. Chouhan, M.S. Thakur, Anal. Biochem. 388 (2009) 312-316.

[15] W. Qin, Z.J. Zhang, H.J. Liu, Anal. Chim. Acta 357 (1997) 127-132.

[16] Q. Wang, D. O’Hare, Chem. Rev. 112 (2012) 4124-4155.

[17] V. Rives, M. del Arco, Cristina Martín, J. Control. Release 169 (2013) 28-39.

[18] S. He, Z. An, M. Wei, D.G. Evans, X. Duan, Chem. Commun. 49 (2013) $5912-5920$

[19] L. Fernández, I. Ledezma, C. Borrás, L.A. Martínez, H. Carrero, Sens. Actuators B 182 (2013) 625-632.

[20] K.A. Tarasov, D. O’Hare, Inorg. Chem. 42 (2003) 1919-1927.
[21] S. Tang, H.K. Lee, Anal. Chem. 85 (2013) 7426-7433.

[22] E.L. Crepaldi, P.C. Pavan, J.B. Valim, J. Mater. Chem. 10 (2000) 1337-1343.

[23] Z.H. Wang, F. Liu, C. Lu, Chem. Commun. 47 (2011) 5479-5481.

[24] L.J. Zhang, Y.C. Chen, Z.M. Zhang, C. Lu, Sens. Actuators B 193 (2014) 752-758.

[25] W.J. Guan, W.J. Zhou, Q.W. Huang, C. Lu, J. Phys. Chem. C 118 (2014) $2792-2798$.

[26] Z.H. Wang, X. Teng, C. Lu, Anal. Chem. 85 (2013) 2436-2442.

[27] M.C. Zhang, D.M. Han, C. Lu, J.-M. Lin, J. Phys. Chem. C 116 (2012) 6371-6375.

[28] Z.H. Wang, X. Teng, C. Lu, Analyst 137 (2012) 1876-1881.

[29] S.C. Dong, W.J. Guan, C. Lu, Sens. Actuators B 188 (2013) 597-602.

[30] W.J. Guan, W.J. Zhou, D.M. Han, M.C. Zhang, C. Lu, J.-M. Lin, Talanta 120 (2014) $268-273$.

[31] L.J. Zhang, Z.M. Zhang, C. Lu, J.-M. Lin, J. Phys. Chem. C 116 (2012) 14711-14716.

[32] Y.I. Sung, J.W. Jang, H.B. Lim, Analyst 136 (2011) 3872-3876.

[33] A. Economou, A.K. Clark, P.R. Fielden, Analyst 126 (2001) 109-113.

[34] A. Kładna, H.Y. Aboul-Enein, Free Radic. Biol. Med. 34 (2003) 1544-1554.

[35] M.L. Liu, B.X. Li, Z.J. Zhang, J.-M. Lin, Anal. Bioanal. Chem. 381 (2005) 828-832.

[36] S. Chen, W.J. Zhou, Y.Q. Cao, C.C. Xue, C. Lu, J. Phys. Chem. C 118 (2014) 2851-2856. 